DOI: 10.17707/AgricultForest.62.1.06

\author{
Mariia SUBBOTINA, Thomas FISCHER, \\ Lyudmila MIKHAILOVA, Daniil LOSEV ${ }^{I}$
}

\title{
THE INFLUENCE OF POSTAGROGENIC TRANSFORMATION ON BIOLOGICAL PROPERTIES OF SODDY SHALLOW CLAY LOAM PODZOLIC SOIL IN THE PREDURALIE
}

\begin{abstract}
SUMMARY
The aim of this study was to assess changes in biological properties of a postagrogenic soddy shallow clay loam podzolic soil of a 45 years old stationary field experiment of the Perm State Agricultural Academy (Russia) in a graingrass-tilled crop rotation. The design of the experiment facilitated an evaluation of the ecological recovery of fertilized soils as well as of discontinued tillage, where particular emphasis was put on the soil biota. Discontinuation of tillage and high availability of phosphorus and potassium were found to significantly enhance carbon dioxide production and urease activity, and to reduce phosphatase activity. We conclude that elevated amounts of available nutrients enhanced soil biological activity beyond its natural levels, and that preferential recultivation of such areas would minimize the risks of nutrient losses to neighboring environments.

Keywords: fallow land, tillage, carbon dioxide emissions, urease activity, alkaline phosphatase activity

\section{INTRODUCTION}

Fallow land is a potentially valuable resource of the Russian Federation. In Russia, there are located more than 70 million hectares of unused farmland, mainly in areas with low bioclimatic potential: in the northern and eastern regions, as well as in the non-chernozem zone. These lands mainly belong to small farms or to private owners not involved in agriculture [2]. Discontinuation of cultivation resulted, for example, in an increase of pastures in Russia. The Ministry of Agriculture of the Russian Federation is interested in expanding arable areas through the development of fallow land to improve the food and food base of the country. According to the state program of agricultural development for 2013-2020, the funding of Russian farms is provided per hectare, which will entail an intensive process of return to agricultural use of areas under fallow [3]. Conservation and soil improvement can be achieved by science-based land management.
\end{abstract}

Mariia Subbotina,, Lyudmila Mikhailova, Daniil Losev, (corresponding author: subbotina@mail.ru), Permian State Agricultural Academy, 23 Petropavlovskaya str., Perm 614990, RUSSIA, Thomas Fischer, BTU Cottbus, Central Analytical Laboratory, Cottbus, GERMANY Paper presented at the $6^{\text {th }}$ International Scientific Agricultural Symposium "AGROSYM 2015 ". Notes: The authors declare that they have no conflicts of interest. Authorship Form signed online. 


\section{MATERIAL AND METHODS}

The study side was located on an experimental field of a 45 years old stationary field experiment of the Agrochemistry Department of the Perm State Agricultural Academy (Perm, Russia) on a very gentle slope with south-eastern exposure. The soil was a soddy shallow clay loam podzolic soil which has developed on red calcareous clayey loams of the Perm period.

The climate of this region is continental, with cold and long snowy winters and short warm summers. The typical vegetation in 2014 is presented in table 1 and figure 1.

Since 1969, in this experiment was conducted research on the effectiveness of various fertilizer systems, and on the forms and doses of fertilizers in a graingrass-tilled crop rotation. The unique duration of the field experiment under controlled conditions of agronomic management has lead to the establishment of specific environmental effects.

Table 1 Botanical description of study site, 2014

\begin{tabular}{|c|c|c|c|c|}
\hline \multirow{2}{*}{ Variant } & \multicolumn{2}{|c|}{ Projective coverage, $\%$} & \multicolumn{2}{c|}{ Species } \\
\cline { 2 - 5 } & live & dead & grass & trees \\
\hline I & 54 & 42 & $\begin{array}{c}\text { Taraxacum officinale, Sonchus } \\
\text { arvensis, Cirsium arvense Trifolium } \\
\text { repens, Matricaria recutita }\end{array}$ & $\begin{array}{c}\text { Alnus } \\
\text { incána, }\end{array}$ \\
\hline II & 61 & 51 & $\begin{array}{c}\text { Taraxacum officinale, Sonchus } \\
\text { arvensis, Cirsium arvense, } \\
\text { Matricaria recutita, Plantágo } \\
\text { májor }\end{array}$ & $\begin{array}{c}\text { Alnus } \\
\text { incána, } \\
\text { Acer } \\
\text { negúndo }\end{array}$ \\
\hline III & 5 & 2 & Matricaria recutita & - \\
\hline
\end{tabular}

The postagrogenic phytocenosis of fallow variants (I and II) was presented by ruderal vegetation with dominating Taraxacum officinale and Sonchus arvensis. Plant residues consisted of leaves and straw. The projective coverages of live and dead vegetation were $12-20 \%$ higher in variant II compared to variant I. Mosses or other cryptogams did not form layers or biocrusts.
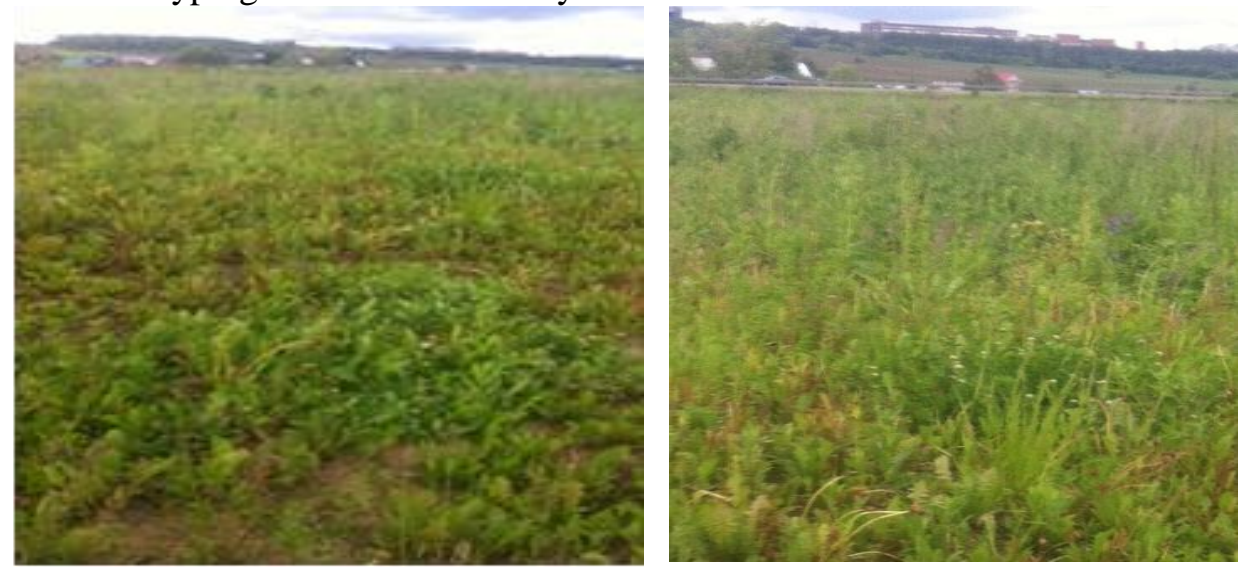

Figure 1 . View of study site ( $\mathrm{a}$ - I variant; $\mathrm{b}$ - II variant) 
Levels of available phosphorus and exchangeable potassium established during the experiment (Table 2) further influenced the productivity of the phytocenoses.

Total biomass was higher by $15-23 \%$ in the variant with high phosphoruspotassium background compared to the control. Thus, agricultural crops and the level of mineral nutrition had a significant impact on the development of successions, which further influenced pedogenesis.

To study changes of edaphic properties, soil samples were taken in triplicate from the arable horizon of the following variants: (I) no tillage, no fertilization (fallow control), (II) no tillage with high levels of available forms of phosphorus and potassium (set by the experiment to $150 \mathrm{mg} \mathrm{kg}-1$ ), and (III) tillage only, no fertilization (severely disturbed). Variants (I) and (II) were discontinued in 2011, variant (III) was continued to be cultivated to sampling. Thus, the following effects on biological activity could be studied:

- Variant (i) vs. Variant (ii): ecological recovery of fertilized soil

- Variant (i) vs. Variant (iii): influence of tillage

- Variant (ii) vs. Variant (iii): mutual exclusion of tillage and fertilization Available phosphorus and exchangeable potassium were determined in extracts of $0,2 \mathrm{~m} \mathrm{kcl}$ solution with a ratio of 1:5. The soddy shallow clay loam podzolic soil was characterized by a slightly acidic reaction and by high degrees of base saturation (v)

Table 2. Agrochemical properties of soddy shallow clay loam

\begin{tabular}{|c|c|c|c|c|c|c|c|}
\hline \multirow{2}{*}{ Variant } & \multirow{2}{*}{$\mathrm{pH}_{\mathrm{H} 2 \mathrm{O}}$} & \multirow{2}{*}{$\mathrm{pH}_{\mathrm{KCl}}$} & \multicolumn{2}{c|}{$\begin{array}{c}\text { mg-eqv/100 g of } \\
\text { soil }\end{array}$} & \multicolumn{2}{c|}{$\mathrm{V} \%$} & \multicolumn{2}{c|}{$\mathrm{Mg} / \mathrm{kg}$ of soil } \\
\cline { 5 - 8 } & & & $\mathrm{Sum}$ & $\mathrm{CEC}$ & & $\mathrm{P}_{2} \mathrm{O}_{5}$ & $\mathrm{~K}_{2} \mathrm{O}$ \\
\hline I & 6.4 & 5.0 & 17.3 & 19.6 & 89 & 101 & 142 \\
\hline II & 6.4 & 5.3 & 18.5 & 20.8 & 89 & 161 & 190 \\
\hline III & 6.4 & 5.3 & 14.4 & 16.8 & 86 & 150 & 168 \\
\hline
\end{tabular}

Respiratory activity was determined every two weeks in summer 2014 by $\mathrm{CO}_{2}$ adsorption using the method of shtatnov in modification of makarov (1975). Enzyme activities were determined using spectrophotometric methods: urease according to hoffmann and teicher (1961); alkaline phosphatase according to tabatabai and bremner (1969).

\section{RESULTS AND DISCUSSION}

Surface carbon dioxide emission differed significantly between all variants, and further depended on other factors, like temperature and humidity (sampling date comprised $37 \%$ of total variance) (Figure 1). For the tillage only 
variant (III) the soil respiration rate was minimal in all periods of measurement and averaged to $2.2 \pm 1.2 \mathrm{~kg} \mathrm{CO} \times$ ha- $1 \times \mathrm{h}-1(59 \pm 10 \%$ of control, sampling date effects excluded in relative data), expressing the negative effect of severe disturbance on soil biota.

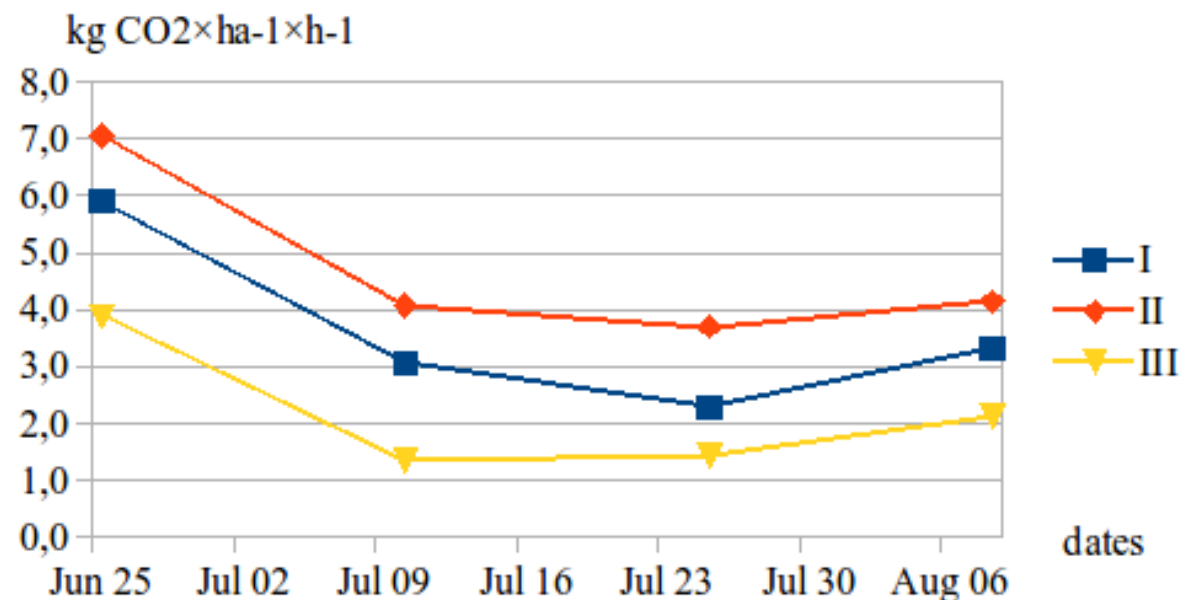

Figure 2: Carbon dioxide emissions of soddy shallow clay loam podzolic soil, 2014.

On the control plots under fallow, $\mathrm{CO}_{2}$ discharge averaged to $3.6 \pm 1.6$ $\mathrm{CO}_{2} \times$ ha- $1 \times \mathrm{h}-1$, and in variant (II) with high phosphorus-potassium background it was highest $(4.7 \pm 1.6 \mathrm{~kg} \mathrm{CO} \times$ ha- $1 \times \mathrm{h}-1,135 \pm 19 \%$ of control). The results of urease activity confirm this finding (Table 1). On the fallow control it was 13$40 \%$ higher compared to the tillage only variant.

Urease activity averaged to $19.5 \mathrm{mg} \mathrm{N}-\mathrm{NH}_{3} \times 24 \mathrm{~h}-1 \times 10 \mathrm{~g}-1$ soil in the tillage only variant (III), to $22.3 \mathrm{mg} \mathrm{N}-\mathrm{NH}_{3} \times 24 \mathrm{~h}-1 \times 10 \mathrm{~g}-1$ soil in the control, and to $31.4 \mathrm{mg} \mathrm{N}-\mathrm{NH}_{3} \times 24 \mathrm{~h}-1 \times 10 \mathrm{~g}-1$ soil in variant (II) with high phosphoruspotassium background.Thus, humus turnover and urease activity remained on higher levels in variant (II) after discontinuation of the field experiment, presumably due to persisting favorable conditions for vegetation development and soil biota.

Table 3 Enzyme activities of soddy shallow clay loam podzolic soil, 2014

\begin{tabular}{|c|c|c|}
\hline Variant & $\begin{array}{c}\text { Urease, } \mathrm{mg} \mathrm{N}^{-\mathrm{NH}_{3} \times} \\
\times 24 \mathrm{~h}^{-1} \times 10 \mathrm{~g}^{-1} \text { soil }\end{array}$ & $\begin{array}{c}\text { Phosphatase, } \mathrm{mg}_{2} \mathrm{O}_{5} \times \\
\times \mathrm{h}^{-1} \times \mathrm{g}^{-1} \text { soil }\end{array}$ \\
\hline I (fallow control) & 22.3 & 12.0 \\
\hline II (high PK background) & 31.4 & 8.7 \\
\hline III (tillage only) & 19.5 & 16.7 \\
\hline LSD $_{01}$ & 4,0 & 4,4 \\
\hline
\end{tabular}


The phosphatase activity was inversely related to concentrations of mobile phosphates, indicating that phosphatase activity decreases with phosphate availability. For the control, the activity was $12.0 \pm 1.1 \mathrm{mg} \mathrm{P}_{2} \mathrm{O}_{5} \times \mathrm{h}-1 \times \mathrm{g}^{-1}$ soil; for variant (II) with high phosphorus-potassium background $8.7 \pm 2.8 \mathrm{mg} \mathrm{P}_{2} \mathrm{O}_{5} \times \mathrm{h}$ $1 \times \mathrm{g}^{-1}$ soil, and significantly higher on the tillage only variant (III) $-16.7 \pm 0.7 \mathrm{mg}$ $\mathrm{P}_{2} \mathrm{O}_{5} \times \mathrm{h}-1 \times \mathrm{g}^{-1}$.

\section{CONCLUSIONS}

It was concluded that elevated amounts of available nutrients enhanced soil biological activity beyond its natural levels. Preferential recultivation of such areas would promote food production and minimize the risks of nutrient output to their neighboring environment. It is further proposed that fallow facilitates the restoration of soil functionality in case of severe agrogenic disturbance.

\section{ACKNOWLEDGEMENTS}

This study was supported by Ministry of Agriculture of the Russian Federation in 2014. We thank our analytical laboratory represented by Irina Yashinina, Victor Murygin, Lubov Vorontcova for performing all analyses.

\section{REFERENCES}

Hoffmann G., Teicher K. (1961) Ein kolorimetrisches Verfahren zur Bestimmung der Urease-aktiviatim Boden // Ibid.Bd. 65. Nr1. S. 55-63. http://www.hse.ru/data/2011/10/20/1268961571/report.doc Accessed on 03/11/2014. http://www.mcx.ru/navigation/docfeeder/show/342.htm Accessed on 25/11/2014.

Makarov B. (1975) Agrokhimicheskie metody issledovaniya pochv. Nauka. Moscow. Orlov D., Sadovnikova L., Sukhanova N. (2005) Khimiia pochv. Moscow.

Tabatabai M.A., Bremner J.M. (1969) Use of p-nitrophenyl phosphate for assay of soil phosphatase activity // Soil Biol. and Biochem. Vol. 1. No. 4. P. 301-307. 